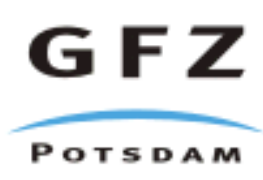

Originally published as:

Vieth, A., Mangelsdorf, K., Sykes, R., Horsfield, B. (2008): Water extraction of coals potential for estimating low molecular weight organic acids as carbon feedstock for the deep terrestrial biosphere. - Organic Geochemistry, 39, 8, 985-991,

DOI: 10.1016/j.orggeochem.2008.02.012. 


\title{
Water extraction of coals - potential to estimate low molecular weight organic acids as carbon feedstock for the deep terrestrial biosphere?
}

\author{
Andrea Vieth $^{\mathrm{a}, \star}$, Kai Mangelsdorf ${ }^{\mathrm{a}}$, Richard Sykes $^{\mathrm{b}}$, Brian Horsfield $^{\mathrm{a}}$ \\ ${ }^{\mathrm{a} G e o F o r s c h u n g s Z e n t r u m ~ P o t s d a m, ~ O r g a n i c ~ G e o c h e m i s t r y, ~ T e l e g r a f e n b e r g, ~}$ \\ D-14473 Potsdam, Germany \\ ${ }^{\mathrm{b}}$ GNS Science, PO Box 30-368, Lower Hutt 5040, New Zealand

\begin{abstract}
*GeoForschungsZentrum (GFZ) Potsdam, Organic Geochemistry, Telegrafenberg, D-14473 Potsdam, Germany; phone: ++49-331-2881431; fax: ++49-331-2881436;

e-mail: vieth@gfz-potsdam.de
\end{abstract}

\begin{abstract}
With the recent increasing interest in the deep biosphere, the question arises where the carbon sources that support deep microbial communities are derived from. Therefore, our research is focussed on the water-soluble low molecular weight organic acids that are potentially available from different sedimentary lithologies to serve as a carbon source to feed the deep biosphere. A series of Eocene-Pleistocene coals, mudstones and sandstones of varying rank (maturity) and organic carbon content from the Waikato Basin, New Zealand, has been Soxhlet-extracted using water. The combined concentrations of formate, acetate and oxalate recovered range from 366 to $2499 \mu \mathrm{g}$ per g sediment and appear to
\end{abstract}


be dependent on rank, organofacies and TOC. The recovered yields of low molecular weight organic acids indicate the potential of carbonaceous sediments to feed the local deep terrestrial biosphere over geological periods of time. The existence of living microbial organisms in the mudstones and sandstones was proven by the identification of intact phospholipids.

\section{Introduction}

Within the last decades, research about microbial life, its diversity and biogeochemical processes in deep marine and terrestrial systems has gained importance. The existence of life in these extreme environments has raised the question of where the carbon source for microbial life is derived from. It remains poorly understood which fractions of the sedimentary organic material are accessible to microbial degradation and on what timescale these fractions are digested, oxidized and assimilated (Jørgensen and Boetius, 2007). Focussing on deep terrestrial systems there have been limited studies on the microbiology of subsurface lignite/coal formations. These studies indicate that anaerobic prokaryotic processes occur (Kanduc and Pezdic, 2005) and are stimulated close to lignite layers (Ulrich et al., 1998; Detmers et al., 2001) or by the organic material trapped in shales (Krumholz et al., 1997). Heating experiments with kerogen and humic acids resulted in the release of low molecular weight monoand dicarboxylic acids (Kawamura and Kaplan, 1987; Barth et al., 1988). Monocarboxylic acids are also present in oil-formation waters (Carothers and Kharaka, 1978). Low molecular weight organic acids (LMWOA) such as acetate, formate and oxalate have been shown to be extractable from low-rank coals with water in a Soxhlet apparatus (Bou-Raad et al., 2000). In their publication, Bou-Raad and 
co-workers (2000) stated that the amount of oxalate released was negatively correlated to the rank of the coal samples. Pyrolysis of coals led to high amounts of formate and acetate and low amounts of these compounds have already been detected even after washing the coal samples (Quyn et al., 2002). This indicates that low rank coals can provide LMWOA which may decarboxylate to yield hydrocarbons or be consumed by microorganisms. These LMWOA have been evaluated as direct natural gas precursors via thermal cracking as well as potential substrates for methanogenic activities (Parkes et al., 2000; Horsfield et al., 2006).

The focus of our research is the potential of low-rank coals and associated lithologies with lower organic carbon content (e.g., mudstones and sandstones) to release LMWOA as a feedstock for an in-situ microbial community, the existence of which we confirm through phospholipid analysis. We also sought to demonstrate that the extraction of coals and clastic sediments with water may present a first tentative estimate of the amounts of LMWOA that are easily available in deep terrestrial systems.

\section{Materials and Methods}

\subsection{The DEBITS site}

Samples were taken from the DEBITS (DEep Biosphere In Ierrestrial $\underline{\text { Systems) }}$ borehole located in a farm paddock near Huntly, New Zealand (37'29' 26.2351" $\left.\mathrm{S}, 175^{\circ} 10^{\prime} 51.0115^{\prime \prime} \mathrm{E}\right)$. The penetrated sequence comprises about $69 \mathrm{~m}$ of moderately indurated, Late Eocene-Early Oligocene Te Kuiti Group sandstones, mudstones (siltstones and claystones) and interbedded, sub-bituminous coals, unconformably overlain by about $76 \mathrm{~m}$ of Latest Miocene-Late Pleistocene 
Tauranga Group sediments comprising poorly consolidated gravels, sands, muds and interbedded coals of lignite rank. Sediments below the unconformity at $76 \mathrm{~m}$ depth were previously buried to estimated depths and temperatures of $2000 \mathrm{~m}$ and $75^{\circ} \mathrm{C}$, prior to Middle-Late Miocene uplift and as a result, the Te Kuiti Group coals are of significantly higher, sub-bituminous rank $\left(R_{0} \sim 0.39 \%\right)$ than the lignites $\left(\mathrm{R}_{0} \sim 0.29 \%\right)$ of the overlying Tauranga Group. The total moisture (54.9$65.6 \%)$ and bitumen (7.7-53.4 mg HC/g TOC) contents of the Tauranga Group coals and coaly mudstones are consequently much greater than those of the Te Kuiti Group coals and coaly mudstones (23.2-27.2 \% and 0.9-3.6 mg HC/g TOC). The shallower, Tauranga Group sequence contains five groundwater aquifers (3.0-17.0; 23.8-25.0; 29.3-30.9; 34.6-39.3 and 66.7-67.0 $\mathrm{m}$ below surface). Groundwater measurements were affected by drilling mud contamination, but temperature and $\mathrm{pH}$ readings were mainly within the ranges 16.5-18.1 ${ }^{\circ} \mathrm{C}$ and 6.4-8.3, respectively. A single dissolved oxygen value of 1.6 ppm for the shallowest aquifer suggests suboxic conditions. Further information about the drilling, contamination control and sampling is presented in Kallmeyer et al. (2006).

For the present study, coal samples were selected from five different depths to evaluate the effect of thermal maturation on the potential to release organic carbon compounds. Three lignitic coals (Coal A-C) were collected from above the unconformity, and two sub-bituminous coals (Coal D and E) from below. An additional five samples of varying lithology (Interface A-E) were taken covering a transect from the youngest lignite seam (at about $18 \mathrm{~m}$ depth) into the underlying mudstone and sandstone layers (Table 1). 


\subsection{Soxhlet extraction of samples}

The selected samples were freeze-dried and ground and then extracted with water for 2 days using conventional Soxhlet apparatus. For all extractions and analytical work deionized water was used that had been treated by UVphotooxidation (Simplicity 185, Millipore) to remove any organic compounds. The Soxhlet apparatus and cellulose thimbles were pre-cleaned for 1 day using 150$250 \mathrm{ml}$ of the purified water. Each finely powdered sample (1-10 g) was extracted with $150-250 \mathrm{ml}$ of the purified water for 2 days. The extraction temperature within the sample thimble was approximately $80{ }^{\circ} \mathrm{C}$. The water extracts were filtered by vacuum filtration using $0.45 \mu \mathrm{m}$ polypropylene filters. The reproducibility of the Soxhlet extraction was tested once, the difference between two individual extractions is below $10 \%$.

Soxhlet extraction of coals and other lithologies with water was considered as being an appropriate method to obtain information about their potential to release LMWOA. In general, due to the continuous circulation of warm solvent the extraction yields of this method are known to be higher than in corresponding batch extraction experiments. The water temperature of approximately $80^{\circ} \mathrm{C}$ is still compatible with microbial life. To date, temperatures between $80-90{ }^{\circ} \mathrm{C}$ are considered maximum temperatures of biological activity in petroleum reservoirs (Connan, 1984; Wilhelms et al., 2001; Head et al., 2003). The higher extraction temperatures used in our experiments compared to the in-situ temperatures have been chosen to compensate the longer extractions times in geological systems, which can hardly be simulated in laboratory experiments. Furthermore, extraction experiments running over longer time spans than 2 days showed that higher amounts of LMWOA can be extracted from coals. A reason for this might be a 
gradual release of these compounds from the complex coal structure, whereas these compounds may be trapped in interstitial spaces and/or sorbed to the matrix. However, being aware that the chosen extraction method is not resembling the in-situ conditions and that the amount of free LMWOA associated with the coal matrix is possibly larger, we applied for practical reasons the described Soxhlet extraction method to obtain a first insight into the potential of different lithologies (mainly organic carbon rich sediments of different maturity) to release LMWOA into surrounding water, hence, forming a potential carbon source for deep microbial communities.

\subsection{Determination of anions}

All water extracts were analysed in replicate by ion chromatography with conductivity detection (ICS 3000, Dionex Corp.). For chromatographic separation of the anions the analytical column AS $11 \mathrm{HC}$ (Dionex Corp.) was used at a temperature of $35{ }^{\circ} \mathrm{C}$. The sample was eluted by $\mathrm{KOH}$ solution of varying concentration over time. The initial $\mathrm{KOH}$ concentration was $0.5 \mathrm{mM}$, maintained for $8 \mathrm{~min}$. After $10 \mathrm{~min}, 15 \mathrm{mM} \mathrm{KOH}$ solution was reached and kept constant for $10 \mathrm{~min}$. After $30 \mathrm{~min}$ analysis time, $60 \mathrm{mM} \mathrm{KOH}$ concentration was reached, followed by a rapid increase to $100 \mathrm{mM}$ after $30.2 \mathrm{~min}$. At $32 \mathrm{~min}$ analysis time, $\mathrm{KOH}$ concentration was again at the initial level of $0.5 \mathrm{mM}$ and kept there for an additional $15 \mathrm{~min}$ to equilibrate the system. For quantification of organic acids (formate, acetate, propionate, butyrate, valerate, oxalate) and inorganic anions $\left(\mathrm{F}^{-}, \mathrm{Cl}^{-}, \mathrm{SO}_{4}{ }^{2-}, \mathrm{NO}_{3}^{-}, \mathrm{PO}_{4}{ }^{3-}\right)$ standards containing all of the investigated compounds were measured in different concentrations every day. Standard deviation of sample and standard quantification is below $10 \%$. 


\section{$\underline{2.4 \quad \text { Detection of intact phospholipids }}$}

To document the occurrence and distribution of viable microbial organisms in the DEBITS transect sediments we analyzed the sample material for intact phospholipids (PLS). These biomarkers are suitable to act as microbial life markers because they rapidly degrade after cell death during early diagenetic processes (e.g. White et al., 1979; Harvey et al., 1986; Rütters et al., 2002; Zink et al., 2003; Sturt et al., 2004). For the analysis of phospholipids we used an extraction method modified after Bligh and Dyer (1959). Afterwards the lipid extract was separated by column chromatography into fractions of different polarity. Finally, the intact phospholipids were detected using a high performance liquid chromatography (HPLC) instrument (Shimadzu SCL-10a VP) coupled to a Finnigan MAT TSQ 7000 mass spectrometer equipped with an electrospray interface (ESI). Details on the phospholipid analysis are described in Zink and Mangelsdorf (2004). For quantification we determined the peak areas of individual phospholipid groups (mass trace of the sum of all molecular ions representing individual PL groups), considering their different response factors relative to the peak area of an internal standard (deuterated $\left(d_{31}\right)$ palmitoyllysophosphatidylcholine) of known concentration as described in Mangelsdorf et al. (2005) and Zink et al. (2008).

\section{Results and Discussion}

\subsection{Extraction of coals of different rank}

Formate, acetate and oxalate were detected in the water extracts of all five DEBITS coals (Fig. 1). The detected concentrations of the three extracted 
LMWOA in the coals of comparable rank either from above or below the unconformity appear to be variable. This is most likely a result of differences in the organofacies of the coals deposited during different time periods. However, in general, greater amounts of LMWOA can be extracted from the lower rank coals above the unconformity. Formate concentrations range between 100 and 1400 $\mu \mathrm{g} / \mathrm{g}$ sediment, with lowest concentrations in the water extracts of the higher rank coal samples from below the unconformity. Acetate concentrations vary from 100 to $500 \mu \mathrm{g} / \mathrm{g}$ sediment. It is obvious that low rank coals released twice as much formate as acetate during extraction whereas for coal samples from below the unconformity the yield of formate is only slightly higher than for acetate. The oxalate concentrations in the water extracts are between 100 to $600 \mu \mathrm{g} / \mathrm{g}$ sediment and show, in general, higher amounts for the lower rank coal samples than for the higher rank coals.

The results show that a significant amount of LMWOA can be released from the coal matrix into the surrounding water. Additionally, this study suggest that lignitic coals $(n=3)$ tend to have larger potential for the release of LMWOA, especially formate, into water than higher rank, sub-bituminous coals $(n=2)$. This general trend may be a result of the degree of diagenetic alteration of the macromolecular organic matter within the coals, leading to a depletion of such easily available small molecules in the macromolecular structure. The variable amounts of water extractable organic acids from low rank coals might be caused by different organofacies or a greater structural heterogeneity of the less mature organic matter compared to the higher rank coals from below the unconformity. Thus, the more mature material appears to provide lower amounts of LMWOA and therefore, indicates a lower potential to serve as feedstock for microbial life in 
underlying terrestrial systems. However, it can be assumed that lower LMWOA yields in the sub-bituminous coals are caused by a previous expulsion of LMWOA during earlier, deeper burial of these coals down to depth of $2000 \mathrm{~m}$ and temperature of approximately $75^{\circ} \mathrm{C}$ (see chapter 2 ) and a potentially associated earlier feeding of the deep biosphere.

\section{$\underline{3.2 \quad \text { Lignites as feedstock for microbial organisms }}$}

To compare the availability of LMWOA from coals and other clastic lithologies, five samples of different lithology from a cored section at $18 \mathrm{~m}$ depth have been extracted. These samples cover a transition from lignite to mudstone to sandstone, with decreasing TOC from 34.6 to $0.2 \%$ (Table 1, Fig. 2a). The water extraction of these so-called "interface samples" similarly resulted in the release of formate, acetate and oxalate (Fig. 2b), with the total amount of acids released decreasing substantially with decreasing TOC.

In addition to the water extraction experiments, the five interface samples were also examined for intact phospholipids, which are indicators of microbial life (White et al., 1979; Zink et al. 2003). The phospholipids detected in the five interface samples were mainly phosphatidylglycerols (Fig. 2a) and phosphatidylethanolamines. The concentration of phospholipids barely exceeded the detection limit in the lignite, which might be somewhat higher than in the adjacent lithologies due to the higher background noise from the organic matrix. Phospholipid concentrations increased in the mudstone layer immediately beneath the lignite, and then decreased again with increasing distance beneath the lignite layer (Fig. 2a). The profile of intact phospholipids appears to confirm the potential of organic carbon-rich lignites and clastic lithologies (e.g. 
carbonaceous mudstones) to feed microbial communities in adjacent sedimentary layers. To date, it is assumed that microbial life preferentially occurs in lithologies with sufficient pore space for its metabolic exchange processes (Fredrickson et al., 1997; Sharma and McInerney, 1994).

The differences in distribution of LMWOA and molecular life-markers may imply that the water soluble organic acids will be transported by diffusion and/or advection from the coal layers to the adjacent carrier lithologies to support the deep biosphere. This general idea of organic carbon-rich lithologies feeding adjacent layers with low molecular weight organic compounds has been previously proposed (Horsfield et al., 2006; Krumholz et al., 1997; McMahon and Chapelle, 1991). Our study has also shown, however, that mudstones (claystones and siltstones) and sandstones with low organic carbon content also have the potential to release low molecular weight organic compounds, but in much lower concentrations.

\subsection{Feeding the deep biosphere - estimation of bioavailable compounds}

In our extraction experiments we observed that the amount of LMWOA released into water under identical extraction conditions is dependent on the maturity and organofacies of the source material (coal samples) and on the TOC content (interface samples). However, if we consider only the five coal samples and the lignite from the transect samples, we find an inverse trend between TOC (\%) and the amount of carbon released as formate, acetate and oxalate, given as percentage of TOC (last column of Table 1). Coal samples with lower TOC (low rank samples) released up to $0.2 \%$ of their TOC as carbon in form of the detected LMWOA. This proportion is significantly lower for the high rank samples, 
where only 0.02 to $0.04 \%$ of their TOC content have been released as LMWOA in water extraction. This is consistent with the idea that increasing thermal maturity is accompanied by polymerisation reactions and structural alteration of the organic matter, resulting in the loss of small, labile and water-soluble substructures (like e.g. LMWOA) within the coal macromolecular structure (Tissot and Welte, 1984). This would limit the amount of carbon that could be released as LMWOA by natural water extraction.

Horsfield et al. (2006) deduced on the basis of metabolic rates published by D'Hondt et al (2002) that $10^{-8}$ to $10^{-11} \mathrm{~g}$ substrate per $\mathrm{g}$ sediment per year can be taken as a rough approximation of microbial rates of substrate utilisation in the deep subsurface. From the coal samples of the DEBITS borehole, summed amounts of formate, acetate and oxalate in the range of 366 to $2499 \mu \mathrm{g}$ LMWOA per $\mathrm{g}$ sediment were released into the water. Assuming that $10^{-8}$ to $10^{-11} \mathrm{~g}$ substrate per $\mathrm{g}$ sediment per year is required to sustain deep microbial life, it can be roughly estimated that the pool of free LMWOA released from the DEBITS coal samples by 2-day water extraction already could serve as a carbon source for an associated microbial community for several thousands to several millions of years. Furthermore, progressive degradation of the organic matter is likely to release more substrates providing an additional feedstock for deep microbial life.

\section{Summary and Conclusions}

Soxhlet extraction of coals with water resulted in the release of LMWOA (formate, acetate and oxalate) being a potential carbon feedstock for deep terrestrial microbial life. The presence of living microbial organisms in mudstones and sandstones adjacent to the coal layers has been proven by phospholipid analysis. 
The mudstones and sandstones themselves, despite very low TOC contents, also provide a source of LMWOA, albeit in much lower concentrations. The proportion of carbon that is released as LMWOA from coal samples appears to be dependent on TOC content, organofacies and maturity. Rough approximations of our 2-day-extraction results showed that this coal-derived fraction of LMWOA may feed the deep terrestrial biosphere for several thousands to millions of years.

\section{Acknowledgement}

We gratefully acknowledge the analytical assistance of Kristin Günther, Cornelia Karger and Annika Wohlers (GFZ Potsdam) and would like to thank Dr. Chris Daughney (GNS Science) for providing groundwater data. We are grateful to an anonymous reviewer and the associate editor for their valuable comments on an earlier draft which helped to improve this publication.

\section{References:}

Barth, T., Borgund, A.E., Hopland, A.L., Graue, A., 1988. Volatile organic acids produced during kerogen maturation - amounts, composition and role in migration of oil. Organic Geochemistry 13, 461-465.

Bligh, E.G., Dyer, W.J., 1959. A rapid method of total lipid extraction and purification. Canadian Journal of Biochemistry and Physiology 37, 911-917.

Bou-Raad, M., Hobday, M.D., Rix, C.J., 2000. Aqueous extraction of oxalate and other anions from coal. Fuel 79, 1185-1193.

Connan, J., 1984. Biodegradation of crude oils in reservoirs. In: Brooks, J.M. and Welte, D.H., Advances in Petroleum Geochemistry. London, Academic Press. Volume 1, 299-355. 
Carothers, W.W., Kharaka, Y.K., 1978. Aliphatic acid anions in oil-field waters; implications for origin of natural gas. American Association of Petroleum Geologists Bulletin 62, 2441-2453.

Detmers, J., Schulte, U., Strauss, H., Kuever, J., 2001. Sulfate reduction at a lignite seam: Microbial abundance and activity. Microbial Ecology 42, 238247.

D'Hondt S., Rutherford S., and Spivack A.J., 2002. Metabolic activity of subsurface life in deep-sea sediments. Science 295, 2067-2070.

Fredrickson, J.K., McKinley, J.P., Bjornstad, B.N., Long, P.E., Ringelberg, D.B., White, D.C., Krumholz, L.R., Suflita, J.M., Colwell, F.S., Lehman, R.M., Phelps, T.J., Onstott, T.C., 1997. Pore-size constraints on the activity and survival of subsurface bacteria in a late Cretaceous shale-sandstone sequence, northwestern New Mexico. Geomicrobiology Journal 14, 183-202.

Harvey, H.R., Fallon, R., Patton, J.S., 1986. The effect of organic matter and oxygen on the degradation of bacterial membrane lipids in marine sediments. Geochemica et Cosmochimica Acta 50, 795-804.

Head, I. M., Jones, D. M., ,Larter, S. R. 2003. Biological activity in the deep subsurface and the origin of heavy oil. Nature 426, 344-352.

Horsfield, B., Schenk, H.J., Zink, K., Ondrak, R., Dieckmann, V., Kallmeyer, J., Mangelsdorf, K., di Primio, R., Wilkes, H., Parkes, R. J., Fry, J., Cragg B., 2006. Living microbial ecosystems within the active zone of catagenesis: Implications for feeding the deep biosphere. Earth and Planetary Science Letters 246, 55-69.

Jørgensen, B.B., Boetius, A., 2007. Feast and famine - microbial life in the deepsea bed. Nature Reviews Microbiology 5, 770-781. 
Kallmeyer, J., Mangelsdorf, K., Cragg, B., Horsfield B., 2006. Techniques for contamination assessment during drilling for terrestrial subsurface sediments. Geomicrobiology Journal 23, 227-239.

Kanduc, T., Pezdic, J., 2005. Origin and distribution of coalbed gases from the Velenje basin, Slovenia. Geochemical Journal 39, 397-409.

Kawamura, K., Kaplan I.R., 1987. Dicarboxylic acids generated by thermal alteration of kerogen and humic acids. Geochimica et Cosmochimica Acta 51, 3201-3207.

Krumholz, L.R., McKinley, J.P., Ulrich, G.A., Suflita, J.M., 1997. Confined subsurface microbial communities in Cretaceous rock. Nature 386, 64-66.

Mangelsdorf, K., Zink, K.-G., Birrien, J.-L., Toffin, L., 2005. A quantitative assessment of pressure dependent adaptive changes in the membrane lipids of a piezosensitive deep sub-seafloor bacterium. Organic Geochemistry 36, 1459-1479.

McMahon, P.B., Chapelle, F.H., 1991. Microbial production of organic acids in aquitard sediments and its role in aquifer geochemistry. Nature 349, 233-235.

Parkes, R.J., Cragg B.A., Wellsbury, P., 2000. Recent studies on bacterial populations and processes in subseafloor sediments: A review. Hydrogeology Journal 8, 11-28.

Quyn, D.M., Wu, H., Bhattacharya, S.P., Li, C.Z., 2002. Volatilisation and catalytic effects of alkali and alkaline earth metallic species during the pyrolysis and gasification of Victorian brown coal. Part II. Effects of chemical form and valence. Fuel 81, 151-158. 
Rütters, H., Sass, H., Cypionka, H., Rullkötter, J., 2002. Phospholipid analysis as a tool to study complex microbial communities in marine sediments. Journal of Microbiological Methods 48, 149-160.

Sharma, P.K., Mclnerney, M.J., 1994. Effect of grain size on bacterial penetration, reproduction, and metabolic activity in porous glass bead chambers. Applied and Environmental Microbiology 60, 1481-1486.

Sturt, H.F., Summons, R.E., Smith, K., Elvert, M., Hinrichs, K.-U., 2004. Intact polar membrane lipids in prokaryotes and sediments deciphered by highperformance liquid chromatography/electrospray ionization multistage mass spectrometry - new biomarkers for biogeochemistry and microbial ecology. Rapid Communications in Mass Spectrometry 18, 617-628.

Tissot, B.P., Welte, D.H., 1984. Petroleum Formation and Occurrence. Springer Verlag, Berlin, pp 699.

Ulrich, G.A., Martino, D., Burger, K., Routh, J., Grossman, E.L., Ammerman, J.W., Suflita, J.M. 1998. Sulfur cycling in the terrestrial subsurface: commensal interactions, spatial scales, and microbial heterogeneity. Microbial Ecology 36, 141-151.

White, D.C., Davis, W.M., Nickels, J.S., King, J.D., Bobbie R.J., 1979. Determination of the sedimentary microbial biomass by extractible lipid phosphate. Oecologia 40, 51-62.

Wilhelms, A., Larter, S.R., Head, I., Farrimond, P., Di Primio, R., Zwach, C. 2001. Biodegradation of oil in uplifted basins prevented by deep-burial sterilization. Nature 411, 1034-1037. 
Zink, K.G., Wilkes, H., Disko, U., Elvert, M., Horsfield B., 2003. Intact phospholipids; microbial "life markers" in marine deep subsurface sediments. Organic Geochemistry 34, 755-769.

Zink, K.G., Mangelsdorf, K., 2004. Efficient and rapid method for extraction of intact phospholipids from sediments combined with molecular structure elucidation using LC-ESI-MS-MS analysis. Analytical and Bioanalytical Chemistry $380,798-812$.

Zink, K.G., Mangelsdorf, K., Granina, L., Horsfield, B., 2008. Estimation of bacterial biomass in subsurface sediments by quantifying intact membrane phospholipids. Analytical and Bioanalytical Chemistry 390, 885-896. 


\section{Tables}

Table 1: Overview of the selected samples from the DEBITS-borehole

\section{Figures}

Figure 1: Concentration ( $\mu \mathrm{g} / \mathrm{g}$ sediment) of formate (triangles), acetate (diamonds) and oxalate (circles) in water extracts of 5 coal samples. The total organic carbon (TOC) content (\%) of the coals (squares) is shown at the right hand side.

Figure 2: Depth profile of the interface samples showing 2a) their total organic carbon (TOC) values (black bars) and their content of phosphatidylglycerols (ng/g sediment; light grey bars) as well as $2 \mathrm{~b}$ ) their concentrations ( $\mu \mathrm{g} / \mathrm{g}$ sediment) of formate (black bars), acetate (light grey bars) and oxalate (grey bars) obtained after water extraction. 
Table 1

\begin{tabular}{llcccc} 
Sample & $\begin{array}{l}\text { Strat. } \\
\text { group }\end{array}$ & $\begin{array}{l}\text { Depth }(\mathrm{m} \text { below } \\
\text { surface })\end{array}$ & Lithology & TOC (\%) & $\begin{array}{c}\text { LMWOA } \\
(\% \text { TOC })^{1}\end{array}$ \\
\hline Coal A & Tauranga & $18.9-19.4$ & coal & 42.6 & 0.11 \\
Coal B & Tauranga & $31.1-31.7$ & coal & 37.4 & 0.20 \\
Coal C & Tauranga & $64.6-65.6$ & coal & 41.1 & 0.09 \\
Coal D & Te Kuiti & $130.4-131.0$ & coal & 57.3 & 0.02 \\
Coal E & Te Kuiti & $141.5-141.7$ & coal & 59.6 & 0.05 \\
\hline Interface A & Tauranga & $18.27-18.37$ & coal & 34.6 & 0.15 \\
Interface B & Tauranga & $18.37-18.44$ & mudstone & 5.2 & n.c. \\
Interface C & Tauranga & $18.44-18.51$ & mudstone & 0.5 & n.c. \\
Interface D & Tauranga & $18.51-18.59$ & fine sandstone & 0.3 & n.c. \\
Interface E & Tauranga & $18.59-18.64$ & med. sandstone & 0.2 & n.c.
\end{tabular}

1 amount of carbon in LMWOA given as percentage of TOC

n.c. not calculated 
Figure 1

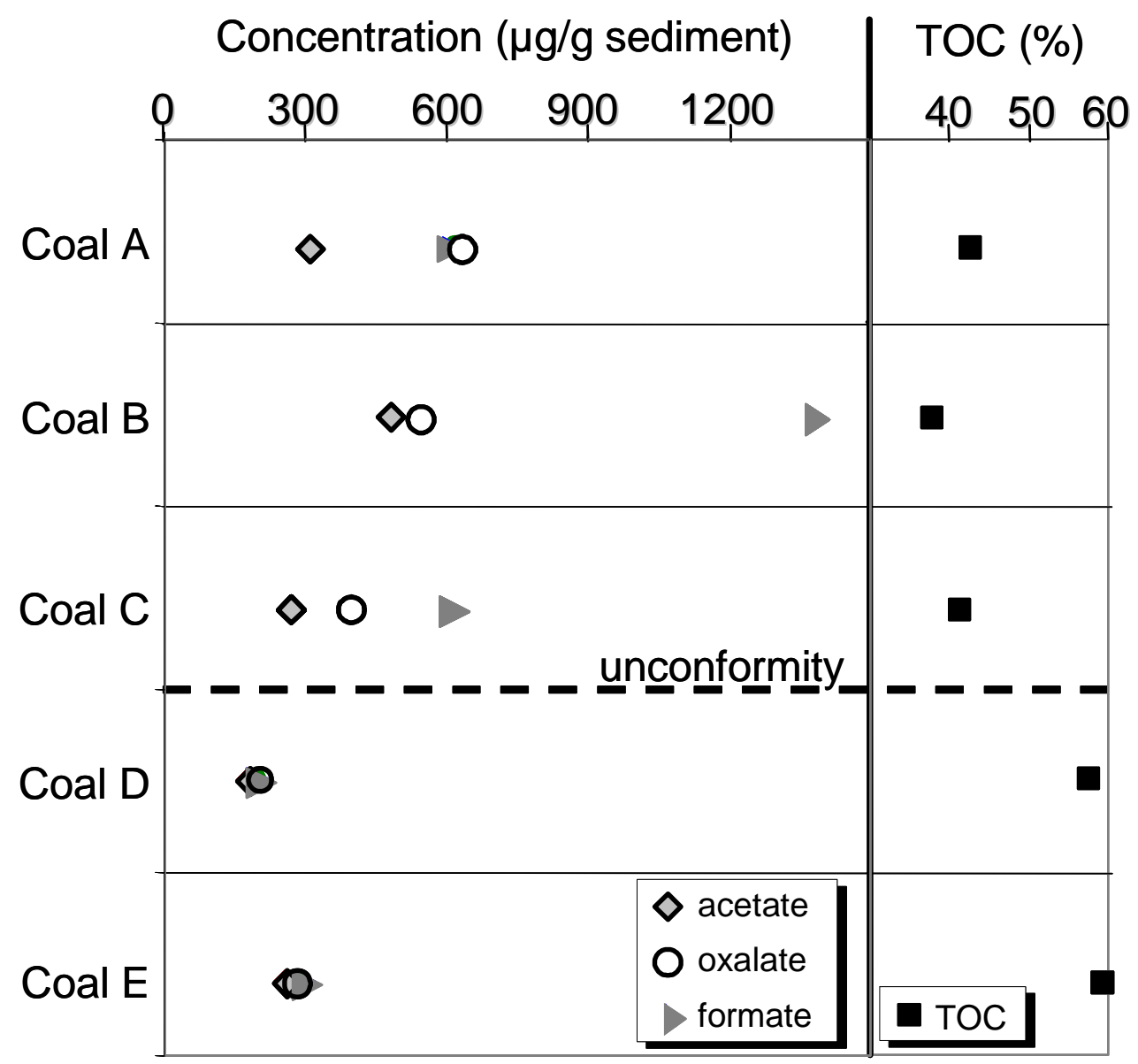


Figure 2

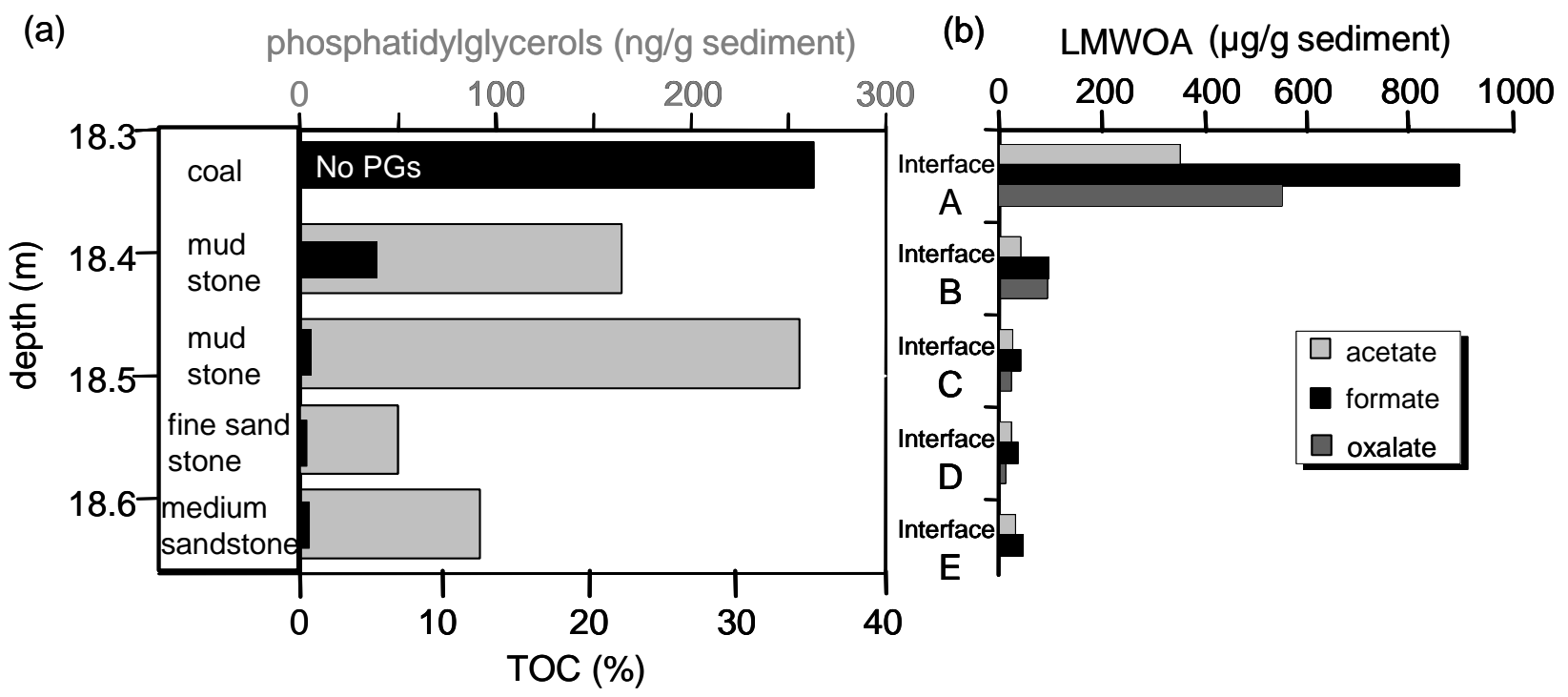


